\title{
Penerapan Pendekatan Kooperatif Tipe Two Stay Two Stray Untuk Meningkatkan Partisipasi Belajar Mahasiswa Pada Mata Kuliah Pembelajaran Terpadu
}

\author{
Natriani Syam ${ }^{1}$, Nurjannah $^{2}$, St. Maryam, M. ${ }^{3}$ \\ 1,2,3 Program Studi PGSD Fakultas Ilmu Pendidikan Universitas Negeri Makassar \\ ${ }^{1}$ natri.syam@gmail.com \\ ${ }^{2}$ nurjannah@unm.ac.id \\ ${ }^{3}$ st.maryam@unm.ac.id
}

\begin{abstract}
The use of conventional learning methods make communication in the learning process exists only in one direction so that students in general passive learning in the classroom and only a few are active to ask, answer and respond to learning. Though learning participation is one of the important factors in learning activities. It is reminded that the teaching and learning activities are held in order to provide learning experiences on the learner. If the students actively participate in learning activities likely learners will be able to extract meaning from that learning. One way that could make students participate in learning that is by applying the learning model. For the purpose of this study was to determine students' increased participation in integrated learning in the classroom C.83 UPP PGSD Parepare FIP UNM by using model two stay two stray. This type of research is classroom action research (PTK). Forms implementation consist of planning, action, observation and reflection. Lasts for two cycles of study. Data analysis technique used is descriptive qualitative data analysis techniques. Be concluded that the application of learning models two stay two stray on the subjects of integrated learning can improve students' participation in class C.83 UPP PGSD Parepare FIP UNM.
\end{abstract}

Keywords: classroom action research, learning model Two Stay Two Stray, study participation.

\section{PENDAHULUAN}

Pada pendidikan di pergururuan tinggi, peran dari pendidik yaitu dosen sangat penting dalam mencapai tujuan pendidikan. Kita ketahui bahwa proses belajar mengajar di kelas merupakan salah satu bagian penting dari pendidikan. Proses belajar mengajar dapat berhasil apabila pendidik kreatif dalam menggunakan pendekatan, model, strategi dan metode yang disesuaikan dengan materi yang diajarkan, begitu pula pada mata kuliah pembelajaran terpadu.

Salah satu cara yang bisa membuat mahasiswa aktif dalam belajar yaitu dengan menerapkan model pembelajaran. Oleh karena itu peneliti ingin menerapkan model Cooperative Learning tipe Two stay two stray dan melihat dampaknya terhadap partisipasi belajar mahasiswa. Dengan model ini mahasiswa bukan hanya belajar dan menerima apa yang disajikan oleh dosen dalam proses belajar mengajar (PBM), melainkan bisa juga belajar dari mahasiswa lainnya, dan sekaligus mempunyai kesempatan untuk membelajarkan mahasiswa yang lain. Bahkan, teknik belajar ini tidak hanya memberikan kesempatan pada mahasiswa untuk saling bekerja sama dan berbagi informasi dengan teman sekelompoknya, namun juga dengan kelompok lainnya, sehingga dengan demikian akan lebih banyak lagi ilmu yang dapat mahasiswa informasikan dengan peserta didik lainnya.

Dengan demikian diasumsikan bahwa penerapan metode pembelajaran Two stay two stray mampu membuat suasana belajar menjadi lebih aktif, partisipatif,kondusif dan menyenangkan. Hal ini dikarenakan mahasiswa juga diberikesempatan untuk berdiskusi secara aktif dalam membahas materi, dalam hal initerutama berdiskusi mengenai model-model pembelajaran terpadu, saling menggali dankemudian berbagi informasi yang mereka dapatkan, sehingga mahasiswa akanmemperoleh pemahaman akan pelajaran yang lebih luas jikadibandingkan dengan belajar menggunakan metode konvensional.

Suprayekti (2006: 89) mengemukakan bahwa cara-cara yang terdapat dalam metode pembelajaran kooperatif ini akan membawa dampak positif bagi peserta didik, diantaranya adalah membangun sikap belajar kelompok/bersosialisasi, membangun kemampuan bekerjasama, melatih kecakapan berkomunikasi, melatih keterlibatan emosi 
peserta didik, mengembangkan rasa percaya diri dalam belajar, meningkatkan prestasi akademiknya secara individu maupun kelompok, meningkatkan motivasi belajar dan membuat peserta didik memperoleh kepuasan dalam belajar.

Salah satu model pembelajaran kooperatif adalah model two stay two stray (TS-TS). Teknik belajar kooperatif tipe two stay two stray (TS-TS) inidikembangkan oleh Kagan. Lie (2004: 61-62) menyatakan bahwa metode inisangat efektif karena dapat digunakan dalam semua mata pelajaran dan untuk semua tingkatan usia didik. Metode belajar ini juga biasa disebut dengan metode "Dua Tinggal Dua Tamu". Metode pembelajaran kooperatif tipe two stay twostray (TS-TS) adalah merupakan salah satu bagian dari metode pembelajaran kooperatif yang menempatkan peserta didik dalam kelompok kecil yang beranggotakan 4 orang. Kemudian mereka diberi tugas untuk membahas meteri pelajaran bersama teman kelompoknya untuk selanjutnya mereka juga akan bertukar anggota untuk sementara guna saling membagikan hasil diskusi dan kerja kelompok untuk didiskusikan kembali dengan anggota kelompok lainnya.

Metode TS-TS melibatkan peserta didik untuk berpartisipasi secara aktif dengan bekerjasama antar peserta didik yang memiliki karakteristik yang berbeda (heterogen) dalam mencapai tujuan pembelajaran yang telah dirancang pengajar sebelumnya dan di sini pengajar berfungsi sebagai fasilitator dan pengayom. Maka pembelajaran ini dimaksudkan agar peserta didik benar-benar menerima ilmu dari pengalaman belajar bersama-sama dengan rekan-rekannya baik yang sudah dikategorikan mampu maupun yang masih dikategorikan lemah dalam memahami konsep/materi pelajaran.

Berdasarkan rumusan masalah dan tinjauan pustaka maka hipotesis tindakan dalam penelitian ini adalah "jika model pembelajaran two stay two stray diterapkan dengan baik, maka partisipasi mahasiswa pada pembelajaran terpadu di kelas C. 83 UPP PGSD Parepare FIP UNM dapat meningkat".

\section{METODE PENELITIAN}

Jenis penelitian ini adalah penelitian tindakan kelas (PTK) atau class action research.Dimana bentuk pelaksanaannya terdiri dari tahap perencanaan, pelaksanaan tindakan, observasi dan refleksi. Tahapantahapan tersebut merupakan tindakan yang berlangsung pada satu siklus penelitian dan berulang pada siklus berikutnya.

Focus dalam penelitian ini yaitu indicator partisipasi belajar mahasiswa dalam hal a) Perhatian mahasiswa dalam mengikuti pembelajaran, b) Menyampaikan pertanyaan, c) Mengemukakan ide, pendapat, jawaban atau sanggahan, dan, d) Mengerjakan tugas dengan baik, yang dilaksanakan pada saat proses belajar mengajar berlangsung dengan menerapkan model two stay two stray.Penelitian tindakan kelas ini dilaksanakan di UPP PGSD Parepare FIP UNM, beralamat di jl. Jend. Sudirman No. 56 Kota Parepare. Kelas yang dipilih yaitu C. 83. Subjek dalam penelitian ini yaitu seluruh mahasiswa di kelas C. 83 yang berjumlah 21 orang.

Data dalam penelitian ini data dikumpulkan dengan cara a) observasi.Dalam penelitian ini hal-hal yang diobservasi yaitu indicator partisipasi belajar mahasiswa serta penerapan model TSTS oleh mahasiswa dan dosen, b) Dokumentasi. Dokumen yang digunakan dalam penelitian iniyaitu daftar hadir mahasiswa pada saat penelitian, hasilkerja tugas mahasiswa, serta foto kegiatan penelitian.

Tekhnik analisis data yang digunakan dalam penelitian ini adalah analisis data deskriptif kualitatif yang dikembangkan oleh Miles dan Huberman, yang terdiri dari tiga tahap, yaitu : a) reduksi data, b) menyajikan data, c) menarik kesimpulan dan verifikasi data.

Indicator keberhasil dalam penelitian ini yaitu jika data hasil penelitian, setelah dianalisis menunjukkan minimal sebagian besar $(75 \%)$ mahasiswa berpartisipasi dalam hal a) perhatian dalam mengikuti pembelajaran, b) Menyampaikan pertanyaan, c) Menyampaikan ide, pendapat, jawaban dan sanggahan, d) Mengerjakan tugas dengan baik pada saat proses belajar mengajar.

\section{HASIL \& PEMBAHASAN}

a. Hasil Penelitian

1) Hasil Penelitian Siklus 1

a) Perencanaan

Pada tahap perencanaan, peneliti mempersiapkan hal-hal yang dibutuhkan saat pelaksanaan penelitian tindakan kelas, antara lain sebagai berikut :

(1) Merancang perangkat pembelajaran yaitu RPP

(2) Membuat lembar observasi aktivitas dosen dalam menerapkan model pembelajaran TSTS. 
(3) Membuat lembar observasi aktivitas mahasiswa dalam menerapkan model pembelajaran TSTS.

(4) Membuat lembar observasi partisipasi belajar mahasiswa.

(5) Menyiapkan kamera yang nantinya akan digunakan untuk mengambil gambar.

b) Pelaksanaan

Diawali dengan dosen menjelaskan ulang garis besar materi model-model pembelajaran terpadu, kemudian membagi mahasiswa ke dalam 5 kelompok, 4 kelompok terdiri dari 4 orang dan 1 kelompok terdiri dari 5 orang. Kemudian mahasiswa diberi tugas untuk dikerjakan dengan kelompok masing-masing.

Pada saat mengerjakan tugas, dosen berkeliling kesetiap kelompok untuk memantau jalannya kerja kelompok. Setelah selesai mengerjakan tugas dengan kelompok masing-masing, dosen meminta dua orang dari masing-masing kelompok meninggalkan kelompoknya dan bertamu ke kelompok lain, dua anggota lainnya bertugas untuk menerima tamu. Dosen memberi penjelasan tentang tugas mereka yaitu dua orang yang bertamu ke kekelompok lain bertugas untuk mencari informasi dan bertanya tentang hasil kerja kelompok yang mereka kunjungi, demikian pula sebaliknya dua orang mahasiswa yang tinggal dalam kelompok bertugas membagikan hasil kerja dan informasi mereka ke setiap tamu yang datang.

Setiap kelompok diberikan kesempatan masing-masing 5 menit untuk bertamu ke tiaptiap kelompok. Setelah semua yang bertugas sebagi tamu telah berkunjung ke semua kelompok, mahasiswa dipersilahkan kembali ke kelompok masing-masing untuk mencocokkan dan membandingkan dengan hasil kerja mereka. Setelah diskusi, dosen mempersilahkan kepada satu orang dari setiap kelompok, untuk membacakan hasil diskusi kelompoknya, dan memberi kesempatan kepada kelompok lain untuk menanggapi hasil diskusi kelompok yang tampil. Setelah semua kelompok selesai membacakan hasil diskusinya, dosen memberi kesimpulan tentang hasil diskusi kemudian menutup pembelajaran hari itu.

c) Observasi

(1) Hasil observasi aktivitas mahasiswa Hasil observasi ativitas belajar mahasiswa menerapkan model pembelajaran TSTS, antara lain sebagai berikut : (a) Pada tahap pembagian kelompok dan pengerjaan tugas berada pada kategori cukup karena semua mahasiswa duduk bersama sesuai dengan kelompok yang telah ditentukan dan mengerjakan tugas yang diberikan melalui diskusi anggota kelompok tapi tidak semua anggota kelompok aktif memberikan masukan.

(b) Tahap dua orang dari tiap-tiap kelompok bertamu ke kelompok lain berada pada kategori pada kategori cukup karena semua kelompok mengutus dua orang sebagai tamu dan setiap tamu dari masing-masing kelompok mendatangi semua kelompok tapi ada beberapa tamu kurang aktif mencari informasi pada kelompok yang dikunjunginya.

(c) Pada tahap dua mahasiswa yang tinggal membagikan informasi dan hasil kerja kepada setiap tamu yang datang berada pada kategori baik karena semua kelompok menerima tamu dari setiap kelompok, menjawab pertanyaan setiap tamu dan membagikan informasi kepada setiap tamu.

(d) Pada tahap kembali ke kelompok masingmasing dan membagikan informasi yang diperoleh dari kelompok lain berada pada kategori cukup karena semua kelompok melaporkan informasi yang diperoleh dari kelompok lain ke anggota kelompoknya dan menyampaikan informasi yang benar tapi kurang jelas.

(e) Pada tahap kelompok mencocokkan dan membahas hasil kerja mereka berada pada kategori cukup karena setiap kelompok mencocokkan dan membahas hasil kerja mereka dan beberapa kelompok mempresentasikan hasil kerjanya tapi kelompok lain tidak ada yang menanggapi hasil kerja kelompok yang presentasi.

Jadi berdasarkan hasil observasi penerapan model pembelajaran TSTS oleh mahasiswa, terlaksana 73,3\% dengan kategori cukup. Hal ini berarti penerapan model TSTS belum sesuai standar indicator keberhasilan yaitu terlaksana minimal $75 \%$ sehingga harus dilanjutkan pada siklus berikutnya.

Jika ditinjau dari tiap-tiap aspek,
partisipasi belajar mahasiswa dengan
menggunakan model TSTS disajikan pada
table berikut:




\begin{tabular}{|l|l|c|c|c|}
\hline No & \multicolumn{1}{|c|}{ Aspek } & $\begin{array}{c}\text { Jumlah skor } \\
(\text { skor max 63) }\end{array}$ & $\%$ & Kriteria \\
\hline 1. & $\begin{array}{l}\text { Perhatian mahasiswa dalam } \\
\text { mengikuti pembelajaran. }\end{array}$ & 45 & $71,4 \%$ & Cukup \\
\hline 2. & Menyampaikan pertanyaan. & 29 & $46 \%$ & Cukup \\
\hline 3. & $\begin{array}{l}\text { Menyampaikan ide, pendapat, } \\
\text { jawaban. }\end{array}$ & 31 & $49 \%$ & Cukup \\
\hline 4. & $\begin{array}{l}\text { Mengerjakan tugas pada proses } \\
\text { pembelajaran }\end{array}$ & 42 & $66,7 \%$ & Cukup \\
\hline
\end{tabular}

(2) Hasil Observasi aktivitas dosen

Berdasarkan data hasil penelitian menunjukkan bahwa persentase penerapan model pembelajaran TSTS oleh dosen dalam proses belajar mengajar adalah sebesar $88,9 \%$ artinya sudah berada pada kategori baik.

\section{d) Refleksi}

Siklus 1 merupakan siklus awal, suasana dalam pembelajaran belum ada perkembangan yang cukup berarti. Keberhasilan dan kegagalan yang terjadi dalam pelaksanaan tindakan selama siklus I dapat diuraikan sebagai berikut :

(1) Masih ada beberapa mahasiswa yang kurang focus memperhatikan penjelasan dosen.

(2) Masing banyak mahasiswa yang kurang aktif dalam mengerjakan dan menyelesaikan tugas kerja kelompok.

(3) Mahasiswa yang lebih pandai mendominasi jalannya diskusi sedangkan mahasiswa lainnya masih pasif.

(4) Mahasiswa masih tampak kaku dalam proses pembelajaran dengan menerapkan model TSTS, terlihat pada saat diberi kesempatan berkunjung pada kelompok lainnya, hanya sedikit mahasiswa yang mau bertanya.

(5) Rata-rata mahasiswa yang bertugas sebagai penerima tamu, aktif dalam memberikan ide, pendapat dan informasi tentang hasil pekerjaan kelompok mereka kepada tamu yang datang berkunjung.

(6) Semua mahasiswa yang melakukan presentasi kelompok, tampil percaya diri.

(7) Dosen belum menerapkan semua langkahlangkah model pembelajaran TSTS dengan maksimal.

Dengan demikian proses pembelajaran akan diperbaiki pada siklus II, yang diharapkan dapat memperbaiki kekurangan pada siklus I, serta meningkatkan partisipasi belajar mahasiswa.
2) Hasil Penelitian Siklus II

a) Perencanaan

Kegiatan yang dilakukan antara lain :

(1) Menyusun rencana pelaksanaan pembelajaran.

(2) Menyiapkan Lembar kerja mahasiswa.

(3) Menyiapkan lembar observasi aktivitas mahasiswa menerapkan model pembelajaran TSTS.

(4) Menyiapkan lembar observasi partisipasi belajar mahasiswa.

(5) Menyiapkan lembar observasi aktivitas dosen menerapkan model pembelajaran TSTS.

(6) Dosen berusaha untuk lebih menguasai model pembelajaran kooperatif tipe two stay two stray.

b) Pelaksanaan

Pada pertemuan ke dua ini, tahaptahap yang dilakukan adalah dosen memberikan penjelasan singkat tentang materi pelajaran hari. itu Selanjutnya dosen menginstruksikan kepada mahasiswa untuk duduk berkelompok sesuai pembagian kelompok pertemuan yang sebelumnya, yaitu terdiri dari 5 kelompok, ada yang beranggotakan 5 orang dan 4 kelompok lainnya beranggotakan 4 orang. Kemudian dosen menginstuksikan kepada mahasiswa untuk mengerjakan tugas secara berkelompok. Dosen membimbing mahasiswa yang sedang berdiskusi, setelah berdiskusi dosen kemudian menginstruksikan kepada dua orang dari tiap kelompok untuk bertugas menerima tamu dan membagikan informasi hasil kerja kelompok mereka kepada tamu yang datang. Dua mahasiswa lainnya dari tiap kelompok bertugas berkunjung ke kelompok lain untuk mencari informasi.

Setelah setiap kelompok berkunjung ke kelompok lain, mereka kemudian kembali ke kelompoknya masing-masing dan menyampaikan informasi yang diperoleh dari kelompok lain. Kemudian dosen mempersilahkan beberapa kelompok 
membacakan hasil diskusinya, kelompok lain diberi kesempatan untuk menanggapi. Semua kelompok tidak diberikan kesempatan untuk membacakan hasil diskusinya karena waktu yang terbatas. Dosen menaggapi dan menyimpulkan hasil diskusi hari itu, kemudian membimbing mahasiswa untuk merangkum materi pelajaran yang telah dilaksanakan.

\section{c) Observasi/pengamatan}

Pengamatan pelaksanaan pembelajaran siklus II diperoleh hasil sebagai berikut :

(1) Hasil observasi aktivitas mahasiswa

Berikut ini hasil dari observasi aktivitas mahasiswa menerapkan model pembelajaran TSTS pada siklus II :

(a) Pada tahap pembagian kelompok dan pengerjaan tugas terlaksana dengan kategori cukup karena semua duduk bersama sesuai dengan kelompok yang telah ditentukan, mengerjakan tugas yang diberikan melalui diskusi anggota kelompok tapi tidak semua anggota kelompok aktif memberikan masukan.

(b) Tahap dua orang dari tiap-tiap kelompok bertamu ke semua kelompok terlaksana dengan kategori cukup karena semua kelompok mengutus dua orang sebagai tamu, setiap 2 tamu dari masing-masing kelompok mendatangi semua kelompok tapi tidak semua tamu aktif meminta informasi pada setiap kelompok yang didatanginya. (c) Tahap dua mahasiswa yang tinggal membagikan informasi dan hasil kerja kepada setiap tamu yang datang terlaksana dengan kategori baik karena semua kelompok menerima tamu dari setiap kelompok, menjawab pertanyaan dari setiap tamu serta membagikan informasi dan hasil kerja kelompok kepada setiap tamu yang datang.

(d) Tahap kembali ke kelompok masingmasing dan melaporkan temuan mereka dari kelompok lain terlaksana dengan kategori baik karena semua kelompok melaporkan informasi yang diperoleh dari kelompok lain ke anggota kelompoknya, informasi yang dilaporkan jelas dan benar

(e) Tahap kelompok mencocokkan dan membahas hasil kerja mereka terlaksana dengan kategori baik karena setiap anggota kelompok mencocokkan dan membahas hasil kerja mereka, beberapa kelompok mempresentasikan hasil kerjanya, dan kelompok lain menanggapi hasil kerja kelompok yang presentasi.

Jadi berdasarkan lembar observasi penerapan model TSTS oleh mahasiswa pada siklus II diperoleh data terlaksana $88,9 \%$ sehingga berada pada kategori baik. Sedangkan jika ditinjau aspek partisipasi belajar mahasiswa dengan menggunakan model pembelajaran TSTS disajikan pada tabel berikut ini :

\begin{tabular}{|l|l|c|c|c|}
\hline No & \multicolumn{1}{|c|}{ Partisipasi belajar mahasiswa } & $\begin{array}{c}\text { Jumlah skor } \\
\text { (skor max 63) }\end{array}$ & $\%$ & Kriteria \\
\hline 1. & $\begin{array}{l}\text { Perhatian mahasiswa dalam mengikuti } \\
\text { pembelajaran. }\end{array}$ & 54 & $85 \%$ & Baik \\
\hline 2. & Menyampaikan pertanyaan & 49 & $77,7 \%$ & Baik \\
\hline 3. & Menyampaikan ide, pendapat \& jawaban & 31 & $79,3 \%$ & Baik \\
\hline 4. & $\begin{array}{l}\text { Mengerjakan tugas dengan baik pada } \\
\text { saat proses pembelajaran. }\end{array}$ & 51 & $80,9 \%$ & Baik \\
\hline
\end{tabular}

(2) Hasil observasi aktivitas dosen

Jadi berdasarkan hasil observasi penerapan model TSTS oleh dosen diperoleh data bahwa penerapan model TSTS terlaksana $88,9 \%$ sehingga berada pada kategori baik. Hal ini berarti indikator keberhasilan yaitu minimal $75 \%$ sudah terpenuhi.

d) Refleksi

Gambaran secara umum pelaksanaan siklus II sudah berjalan dengan baik. Dibawah ini dipaparkan hasil pelaksanaan siklus II : 
(1) Pada tahap pembagian kelompok dan pemberian tugas berada pada kategori baik karena semua mahasiswa telah duduk bersama kelompok yang ditentukan, mengerjakan bersama tugas yang diberikan, dan anggota kelompok aktif memberikan anggota.

(2) Mahasiswa sudah tidak tampak kaku menerapkan model TSTS, karena mahasiswa sudah berani untuk memberikan masukan atas pendapat teman, serta tidak canggung untuk bertanya kepada teman ataupun kepada dosen jika tidak paham atas instruksi dosen maupun dalam pengerjaan diskusi berlangsung.

(3) Dosen sudah optimal menerapkan TSTS

(4) Berdasarkan hasil observasi penerapan model TSTS dan partisipasi belajar mahasiswa sudah mencapai indikator keberhasilan yaitu minimal $75 \%$.

b. Pembahasan

Pada siklus I pelaksanaan model two stay two stray belum dapat berlangsung secara optimal. Hal ini disebabkan model ini merupakan metode baru dalam proses pembelajaran dikelas ini. Mahasiswa masih kaku dan belum terbiasa dengan model pembelajaran yang diterapkan oleh dosen sehingga mahasiswa masih kurang berani dalam menyampaikan pendapatnya.

Hal ini dapat dilihat pada hasil pengamatan partisipasi belajar mahasiswa pada siklus I selama proses pembelajaran TSTS yang difokuskan pada 1) Perhatian mahasiswa dalam mengikuti pembelajaran, 2) Mengemukakan pertanyaan, 3) Mengemukakan ide, pendapat dan sanggahan, dan 4) mengerjakan tugas dengan baik pada saat pembelajaran. Hasil dari observasi siklus I menunjukkan bahwa 1) perhatiaan mahasiswa dalam mengikuti pembelajaran sebesar $71,4 \%$ berarti berada pada kategori cukup, 2) mengemukakan pertanyaan sebesar $46 \%$ berarti berada pada kategori cukup, 3) mengemukakan ide, pendapat, jawaban, sanggahan sebesar $49 \%$ berarti berada pada kategori cukup, dan 4) mengerjakan tugas pada saat pembelajaran sebesar $66,7 \%$ berarti berada pada kategori cukup.

$$
\text { Sedangkan jika ditinjau dari }
$$

keberhasilan penerapan model TSTS menunjukkan bahwa pada siklus I masih ada beberapa tahap yang belum terlaksana dengan baik. Hal tersebut berarti belum mencapai indicator keberhasilan sehingga perlu dilanjutkan ke siklus berikutnya.
Pada siklus II penerapan model TSTS oleh dosen maupun mahasiswa sudah terlaksana dengan kategori baik, sehingga mempengaruhi pula peningkatan partisipasi belajar mahasiswa.

Sedangkan jika ditinjau dari partisipasi belajar mahasiswa menunjukkan bahwa 1) perhatiaan mahasiswa dalam mengikuti pembelajaran memperoleh skor $85 \%$ berada pada kategori baik, 2) mengemukakan pertanyaan sebesar $77,7 \%$ berarti berada pada kategori baik, 3) mengemukakan ide, pendapat, jawaban, sanggahan sebesar $79,3 \%$ berarti berada pada kategori baik, dan 4) mengerjakan tugas pada saat pembelajaran sebesar $80,9 \%$ berarti berada pada kategori baik.

Semua aspek partisipasi belajar mahasiswa telah memenuhi indikator keberhasilan penelitian, hal tersebut berdasarkan pendapat Mulyasa (2011:105) bahwa dari segi proses, pembelajaran dan pembentukan kompetensi dikatakan berhasil dan berkualitas apabila seluruhnya atau setidak-tidaknya sebagian besar (75\%) peserta didik terlibat secara aktif, baik fisik, mental, maupun maupun social dalam proses pembelajaran.

Semua aspek partisipasi belajar mahasiswa telah memenuhi indikator keberhasilan penelitian, hal tersebut berdasarkan pendapat Mulyasa (2011:105) bahwa dari segi proses, pembelajaran dan pembentukan kompetensi dikatakan berhasil dan berkualitas apabila seluruhnya atau setidak-tidaknya sebagian besar (75\%) peserta didik terlibat secara aktif, baik fisik, mental, maupun maupun social dalam proses pembelajaran.

Pada hasil penelitian yang dilakukan di siklus I dan II menunjukkan adanya peningkatan partisipasi belajar mahasiswa. Hal ini disebabkan karena mahasiswa mulai percaya diri dalam menyampaikan pendapatnya, sudah tidak kaku dengan jalannya proses pembelajaran menggunakan model TSTS, serta interaksi mahasiswa dalam mengemukakan pertannyaan dan pendapat sudah tidak kaku dan malu lagi.

Berdasarkan hasil penelitian dapat ditarik kesimpulan bahwa model TSTS efektif digunakan sebagai salah satu alternatif pendekatan model pembelajaran karena dengan menggunakan model tersebut dapat meningkatkan partisipasi belajar mahasiswa. Hal tersebut sejalan dengan pendapat Djumingin (2011 : 181) bahwa keunggulan model TSTS adalah membantu siswa untuk 
memiliki beberapa keterampilan social, seperti bekerja sama, berbagi tugas, mendengarkan pendapat orang lain, menghargai pendapat orang lain, kemampuan bertanya dan lain-lain yang sangat jarang dalam penerapan pembelajaran tradisional.

\section{KESIMPULAN \& SARAN}

Berdasarkan hasil penelitian dan pembahasan dapat ditarik kesimpulan bahwa penerapan model pembelajaran two stay two stray pada mata pelajaran pembelajaran terpadu dapat meningkatkan partisipasi belajar mahasiswa di kelas C.83 UPP PGSD Parepare FIP UNM, karena indikator partisipasi belajar mahasiswa pada siklus II diperoleh hasil bahwa 1) perhatiaan mahasiswa dalam mengikuti pembelajaran memperoleh skor 85\% (kategori baik), 2) mengemukakan pertanyaan sebesar $77,7 \%$ (kategori baik), 3) mengemukakan ide, pendapat, jawaban, sanggahan sebesar 79,3\% (kategori baik), dan 4) mengerjakan tugas pada saat pembelajaran sebesar $80,9 \%$ (kategori baik).

\section{DAFTAR PUSTAKA}

Djumingin, Sulastriningsih. 2011. Strategi dan Aplikasi. Model Pembelajaran Inovatif. Makassar : Badan Penerbit Universitas Negeri Makassar.

Hasibuan \& Moedjiono. 2006. Proses Belajar Mengajar. Bandung : Remaja Rosdakarya.

Lie, Anita. 2004. Cooperative Learning, Mempraktikkan Cooperative Learning Di Ruang-Ruang Kelas. Jakarta : Grasindo.

Mulyasa. 2011. Standar Kompetensi Dan Sertifikasi Guru. Bandung : PT. Remaja Rosdakarya.

\section{Kurikulum Berbasis}

Kompetensi. Bandung : PT. Remaja Rosdakarya.

Nur, Muhammad. 2005. Pembelajaran Kooperatif. Surabaya : Pusat Sains Dan Matematika Sekolah UNESA.

Saud, Udin Saefuddin. Dkk. Pembelajaran Terpadu. Bandung : UPI Press.

Solehatin, Etin Dan Raharjo. 2007. Cooperative Learning : Analisis Model Pembelajaran IPS. Jakarta : Bumi Aksara.

Sardiman. 2011. Interaksi Dan Motivasi Belajar Mengajar. Jakarta : Raja Grafindo Persada.

Sudjana, Nana. 1996. Cara Belajar Siswa Aktif Dalam Proses Belajar Mengajar. Bandung : Sinar Baru Algensindo.
Sudjana \& Rivai. A. 2003. Teknologi Pengajaran. Bandung : Sinar Baru.

Suprayekti.2006. Strategi Penyampaian Pembelajaran Kooperatif. Jurnal Pendidikan. Penabur, No. 07/ Th. V / Desember.

Suryobroto. 1997. Proses Belajar Mengajar Di Sekolah. Jakarta : Rhineka Cipta. 